\title{
Legal Protection For Consumers on The Circulation of Illegal Medicines in West Nusa Tenggara
}

\author{
Muhammad Sood* \\ Department of International Relations \\ University of Mataram \\ Mataram, Indonesia
}

\author{
Lalu Puttrawandi \\ Department of International Relations \\ University of Mataram \\ Mataram, Indonesia
}

\author{
Khairur Rizki \\ Department of International Relations \\ University of Mataram \\ Mataram, Indonesia
}

\begin{abstract}
This study aims to analyze the factors that cause illegal drug products to enter and circulate in West Nusa Tenggara, as well as to analyze the efforts to overcome the circulation of illegal medicinal products to protect consumers. This research is a normative empirical (socio-legal) study that examines various legal norms on drugs which are then combined with field studies. The approach used in addition to the normative approach is also sociological, thus the data source used is not only primary data but also secondary data. The results showed that the cause of the entry and circulation of illegal drugs in West Nusa Tenggara was due to weak regulations regarding the circulation of drugs. The limits of institutional authority in drug control in the field have not been regulated. In addition, the provisions of legal sanctions are also very light. Likewise, the role of institutions in monitoring drug distribution is also weak. The legal culture factor of society, especially the mentality of producers, distributors and consumers is also still weak. This is because their knowledge of the quality and safety standards of medicines is still low. Efforts to overcome the circulation of illegal drugs can be done in a preventive manner, such as improving regulations on the production, registration and awareness of drugs; The role of institutions in monitoring the circulation of medicinal products is not only carried out by BPOM but also by other institutions, both before drug products are marketed (pre-market) and after being marketed (post market); guidance and outreach need to be done to increase awareness and knowledge of drug producers, distributors and consumers. Furthermore, repressive law enforcement must be carried out through the imposition of sanctions for producers, distributors and use of illegal drugs, both administrative, civil and criminal sanctions.
\end{abstract}

Keywords - protection, supervision, distribution, illegal medicines, consumers.

\section{INTRODUCTION}

Medicine is an important element in public health services. Public health services always begin with efforts to prevent, diagnose, treat and recover. Medicines are an important component that is always available and irreplaceable in health care. But on the other hand, drugs can also cause bad effects on health if they do not meet the requirements, or are used inappropriately or misused. The accuracy of using drugs must be considered to avoid risks that are bad for human health. Therefore the production, importation, distribution and use of drugs must be regulated in a different regulation from other trading commodities because this is closely related to the safety and health of the human mind and body.

The increase in medicinal products seems to be of great benefit to consumers because the need for the medicinal product can be fulfilled, but it is not realized that not all medicinal products meet health and safety standards for consumers. The free circulation of drugs is in great demand by consumers, this is because these drugs are easily available and sold freely at every drugstore. The circulation of illegal drugs in various parts of Indonesia, including West Nusa Tenggara is increasing. Many people become victims because they buy drugs at drug stores that do not have a business license, besides that these drugs also do not have a distribution permit from the issued Food and Drug Supervisory Agency (BPOM).

To tackle the circulation of illegal drugs, the Mataram Food and Drug Supervisory Center (BBPOM) in collaboration with the Directorate of Drug Research and the Directorate of Special Criminal Investigation (Reskrimsus) of the NTB Regional Police succeeded in securing 32,400 tablets of the Trihexyphenidyl type tranquilizer. This drug is suspected to be marketed on the island of Lombok for illegal medicinal purposes [1]

Based on the description above, by looking at the increasing distribution of illegal drugs in Indonesia, especially in West Nusa Tenggara Province, the problem in this study is, Why do illegal drug products enter and circulate in West Nusa Tenggara and how to overcome the circulation. illegal drug products in the framework of legal protection for consumers in West Nusa Tenggara.

\section{METHODS}

This research is a normative-empirical (socio-legal) research, meaning that in this study, researchers, apart from examining various references and legal norms regarding the circulation of drugs in libraries, are also combined with conducting field analysis, especially in related institutions such as, Center for Drug and Food Control (BBPOM), Health Service, Non-Governmental Protection Institutions, as well as in various drug stores and pharmacies in West Nusa Tenggara.

The approach method used in this research includes, a statutory approach is an approach that is carried out by examining various regulations relating to legal issues concerning the circulation of drugs which have consistency and relevance to the problems raised in this study [2] and a sociological approach is an approach that is conducted to examine the empirical implementation of regulations in the community [3], to overcome the circulation of illegal medicinal products in the framework of legal protection for consumers in West Nusa Tenggara. Therefore the type of data source used is in addition to primary data obtained from the results of field analysis, as well as secondary data obtained from the results of literature analysis. 


\section{RESULTS AND DISCUSSION}

\section{A. Causes of Circulation of Illegal Medicinal Products in West Nusa Tenggara.}

The circulation of illegal drugs has long been circulating in various districts in West Nusa Tenggara. This is based on the results of an investigation conducted by the Mataram BPOM Center in collaboration with the Directorate of Drug Research and the Directorate of Special Criminal Research or as known as Reskrimsus of the NTB Regional Police in the Operation to Eradicate Illegal Food and Drug Products. During the operation, BPOM succeeded in confiscating illegal drugs, such as 27,541 Trihexyphenidyl tablets and Tramadol tablets in Mataram City [4]. Meanwhile, in Central Lombok the Team managed to confiscate 22,500 tablets of tramadol and trihexyphenidyl, and in East Lombok Regency as many as 1610 tablets [5], while in Bima District 30 capsules of $50 \mathrm{mg}$ Tramadol were found, 1 plastic clip containing 3 capsules of $50 \mathrm{mg}$ Tramadol and, 1 strip of thrihexyphenedyl drug containing 10 grains [6].

The cause of the awareness of illegal drugs in West Nusa Tenggara, from a legal aspect, is closely related to the theory of legal effectiveness as stated by Lawrence M. Friedman that, whether the law is effective or not in people's lives, refers to the terminology of the legal system which includes three subsystems, namely the substance of the law, legal structure, and legal culture [7]. Thus, the number of factors causing the circulation of illegal drugs in West Nusa Tenggara based on field analysis can be assessed from three factors, namely:

\section{Legal Substance Factors (Regulation)}

The substance of law is a regulation consisting of substantive rules and regulations on how institutions must act. Juridically, various legal rules governing licensing, importation, distribution and control of medicinal products in Indonesia, such as Law Number 36 Year 2009 concerning Health, Law Number 8 Year 1999 concerning Consumer Protection; Government Regulation Number 102 of 2000 concerning National Standardization; Regulation of the Head of the Drug and Food Control Agency of the Republic of Indonesia Number: 27 of 2013 concerning Supervision of Importation of Drugs and Food into the Territory of the Republic of Indonesia [7].

The government has issued various regulations governing licensing, importation of distribution, and control of medicinal products as mentioned above, but these regulations still have weaknesses, namely:

a. The regulations are still sectoral in nature, and do not yet regulate in detail about coordination and cooperation, the limits for the implementation of the duties of each institution in supervising the circulation of medicinal products, especially in technical regulations. This condition will cause overlapping policies from each institution in the implementation of supervision. This is also influenced by the sectoral egos of the respective institutions which do not comply with other regulations related to the supervision of the circulation of drugs both for imported and domestic drugs, which in turn can affect the effectiveness of controlling imported products in medicines. b. The existence of convoluted policies which refer to different regulations, will also prevent business actors or distributors of medicinal products from carrying out marketing activities for medicinal products in Indonesia. This condition can have an unfavorable effect on the traffic of trafficking and distribution of drugs legally, because it will result in an increase in the circulation of illegal drugs, such as smuggling of illegal drug products by individuals or unauthorized importers through unofficial ports.

c. Likewise, the sanctions given to the dealers or users of illegal drugs are still very weak which prioritizes administrative sanctions and very light criminal sanctions, while civil sanctions in the form of imposition of compensation for the perpetrators have not been regulated at all. The weakness of witnesses will not give a clear effect, it will even provide loopholes that can be exploited by dealers and users to continue to commit violations.

\section{Legal Structure Factors (Legal Institutions)}

The element of the legal structure is the role of a legal institution in supporting the operation of law in a form as a system of bodies, and how the role of the institution in carrying out its functions and duties, as well as how legal institutions play their roles supported by the ability of human resources, and management or governance and infrastructure in law enforcement and enforcement [7].

The factors that cause the weakness of legal institutions so that drugs can enter and circulate in Indonesia are as follows.

a. Limited staff of the Food and Drug Supervisory Agency (BPOM / BBOPM) and field officers, both at the central and regional levels, in carrying out investigations and verification of drug production and distribution activities. This greatly affects the low ability of drug officers to supervise (pre market and post market), so that illegal drug products can enter and circulate in the community.

b. The pattern of supervision carried out by the BPOM and related agencies is not carried out thoroughly, but is randomized by taking only a few samples of medicinal products on the market to be tested, and carried out periodically. This examination pattern contains weaknesses, especially for medicinal products that are not sampled but contain dangerous substances or have expired, this will pose a risk to consumers.

c. The lack of role of the National Certification Bodies (BSN) in the application of SNI to medicinal products is because the application of SNI to medicines is generally still voluntary, not yet a necessity, so producers prefer not to standardize the medicinal products they produce.

d. There is a transfer of trained drug control officers to other agencies not related to their area of expertise, as well as supervision of drug distribution is also delegated to agencies not related to the field of medicine, especially after regional autonomy.

e. The vast area of Indonesian waters, and there are still many traffics of illegal drugs that enter through 
unofficial ports, especially in the border areas between Indonesia and neighboring countries.

f. Weakness in cooperation relations between relevant government agencies in an effort to prevent the entry and circulation of imported medicinal products that do not meet standards in Indonesia.

g. Weakness in law enforcement, especially the sanctions given to perpetrators of non-optimal violations, both producers, importers and dealers of illegal drugs. Likewise, support from related institutions in law enforcement is still very weak, the witnesses imposed on the perpetrators are still very light, so they do not cause a deterrent effect for the perpetrators of violations.

3. Community Legal Culture Factors (Attitudes, community behavior)

Legal culture factors are patterned attitudes, values, principles, ideas or opinions that are structured in such a way as to be embraced by each individual at the individual and group level in society. Legal culture consists of the legal culture of the legal institutions and culture of society [7]

Several factors cause the implementation of legal rules as a result of the weak legal culture of the community related to the compliance of the community with applicable legal norms, so that drugs that do not meet the provisions can circulate in the community. This is caused by several factors as follows:

a. The weakness of mentality and attitude / behavior of business actors in the pharmaceutical sector who only seek profit by taking advantage of consumer needs for medicinal products which have increased without paying attention to the quality and safety of medicinal products produced.

b. The lack of knowledge, skills, and responsibilities of drug producers and distributors regarding the quality and safety of medicines produced and distributed.

c. The low level of consumer awareness about the quality and safety of medicines consumed.

\section{B. Efforts to Overcome the Circulation of Illegal Drugs in the Context of Legal Protection for Consumers}

Various efforts to overcome the circulation of drugs that do not meet the provisions (illegal) in the framework of consumer legal protection can be made through preventive or repressive measures, as follows:

\section{Preventive Legal Protection includes}

Preventive legal protection can be in the form of improving rules or regulations, fostering, disseminating and controlling the production, importation, distribution and use of drugs in the community.

a. The improvement regulations on the production, import and distribution of medicinal products, these regulations should contain provisions regarding the limits for the implementation of the duties of each institution in supervising medicinal products that enter and circulate in the community, as well as provisions on coordination and cooperation between agencies. related to conducting supervision, and the provisions of sanctions other than administrative and criminal sanctions also contain civil witnesses in the form of compensation.

b. The role of related institutions, especially BPOM, must be increased, so that medicinal products to be produced, circulated and sold in Indonesian territory, both local and imported, must be registered with BPOM to obtain distribution permits. Registered medicinal products will obtain a registration number from the BPOM before they can be distributed to the market. This provision applies to all medicinal products that are packaged and use labels in accordance with applicable laws and regulations. This registration number is useful for BPOM to monitor medicinal products circulating in the market.

c. Supervision of the circulation of medicinal products is carried out by the BPOM in collaboration with other government institutions, both before the product is marketed (pre market) and after the product is marketed (post market).

d. Government should continue to provide guidance and socialization to business actors (producers, distributors) and consumers and drug control officers in an effort to increase their awareness of the importance of drug quality for public health and safety.

2. Repressive legal protection includes:

Repressive legal protection in law enforcement in the form of the imposition of witnesses, both administrative sanctions, civil sanctions and criminal sanctions, namely:

a. Application of administrative sanctions, such as: warnings or written warnings to drug business actors; freezing or cancellation of product registration approval letters; temporary suspension of production and distribution of medicinal products; re-export of medicinal products that do not meet the provisions to the country of origin; withdrawal of medicinal products that do not comply with the provisions from the circulation to be destroyed; Cessation of production activities and revocation of Import Certificate for imported medicinal products.

b. The application of civil sanctions in the form of compensation payments has not been implemented at all. This is due to the public's ignorance of their rights to file claims, get advocacy and legal protection. Several complaints made by the Non-Governmental Organization of Consumers (PKSM) to BPOM regarding the losses suffered by consumers to producers, importers or distributors, however, have not been subject to civil sanctions, but are still limited to the imposition of administrative sanctions. In addition, various regulations concerning drugs do not explicitly regulate civil sanctions, but rather prioritize administrative sanctions and criminal sanctions.

c. The application of criminal witnesses has often been carried out through adjudication (court proceedings) against drug products that enter and circulate 
illegally. The perpetrators have indicated that they have committed the criminal act of smuggling and circulating drug products illegally. Several cases of violations committed by business actors from 2010 to 2018 in various areas in West Nusa Tenggara including Mataram City, some of which have become suspects and have been followed up pro justisia with criminal sanctions based on Article 197 and Article 196 of Law Number 36 Year 2009 concerning Health with the threat of a prison sentence of 15 years and or a fine of IDR 1.5 billion. In addition, the suspects may also be subject to Article 62 of Law number 5 of 1997 concerning Psychotropics with the threat of a 5 year prison sentence and / or a fine of 100 million rupiah

\section{CONCLUSION}

Various factors that cause the circulation of illegal drugs in the city of Mataram are due to weak regulations regarding the circulation of drugs, the sanctions imposed on the perpetrators are also very light, besides that the role of related institutions, especially BPOM in monitoring and investigating the circulation of drugs is also still weak. Likewise, the legal culture of the community, especially the mentality of business actors and consumers, is still low, this is because the knowledge, skills, quality and safety of medicines are still low.

Efforts to overcome the circulation of illegal drugs in Mataram City can be carried out in a preventive manner such as improving regulations on production, registration of imports, awareness and control of drugs, setting limits on the implementation of duties of each institution in controlling the distribution of drugs, and containing administrative, civil and criminal sanctions provisions; Besides being carried out by the POM Agency, supervision of the circulation of medicinal products is also carried out by other institutions both before the product is marketed (pre-market) and after the product is marketed (post market); as well as guidance and outreach to producers, distributors and consumers. In addition, repressive legal protection must be carried out, both the imposition of administrative, civil and criminal sanctions.

\section{REFERENCES}

[1] Bayu Pratama, BBPOM NTB Amankan Tablet Obat Penenang Ilegal,https://insidelombok.id/berita-utama, Tgl 9 January 2019

[2] Peter Mahmud Marzuki, Penelitian Hukum, Cet. ke 5 (Jakarta; Kencana, 2009), hal. 92-93

[3] Lihat, Soerjono Soekanto, Pengantar Penelitian Hukum, (Jakarta: UI, 1982), hal. 52

[4] BPOM, Balai Besar Pengawas Obat dan Makanan Mataram Amankan 27.541 Tablet Obat Yang Sering Disalahgunakan, https://www.pom. go.id/ new/view/more/berita/20677, 31 Januari 2020

[5] Radar Lombok, BPOM Sita Ribuan Obat Ilegal, https://radarlombok.co.id/.html, 16 Desember 2020.

[6] Media NTB Com, Polisi Berhasil Unkapkan Tremadol Ilegal di Kabupaten Bima, http://www.mediantb. com, 17 Mei 2019

[7] Lawrence M. Friedman, The Legal System, A Social Science Perspective, (Russel Sage Foundation, 1975), pg. 14-16. 